https://doi.org/10.3126/pragya.v8i01.42422

\title{
Gender and Governance Issues in Local Government
}

\section{- Dipendra Bikram Sijapati*}

\begin{abstract}
This article is based on issues related to gender and good governance on Local Government. The main aim of the article is to find out the issues of gender and good governance on Local Government in Nepal. That means, reducing poverty requires considerable efforts to improving the participation of women, the poor and back-warded people on local governance and they also participate for resource distribution and mobilization. This article is based on cross sectional descriptive and analytical types of research design. Descriptive research aims are to accurately and systematically describe a population, situation or phenomenon. It can answer what, where, when and how questions, but not why questions. It can use a wide variety of research methods to investigate one or more variables. These outcomes suggest that (i) empowering the poor through good governance will expand their economic opportunities and increase their inclusion in the social life of their communities and (ii) the project's framework and approach could be mainstreamed into Nepalese government efforts to promote good governance and to reduce poverty at the grassroots level. The public sector service deliveries are effectively conducted. The unique framework that is applied for three pillars at the grassroots level. They are resources included employment opportunities, training programs and social sector programs. Nepalese law enforces the reserve seats for women in local governments, but traditionally of gender inequality and patriarchal values have limited the participation and effectiveness of female representatives.It also affect the interface among women representatives, government officials, and poor constituents with social mobilization and capacity building to improve the effectiveness of women representatives and empower them to represent their poor constituents and deliver the services and opportunities they so desperately need. Capacity building provided the require knowledge, skills, and techniques to women representatives, and local resources were mobilized for their poorest constituents. The fact that a majority of the women representatives were themselves deprived that the training and support.
\end{abstract}

Key WordS: Good governance, resource mobilization, gender representation, local government and development

\footnotetext{
*Mr. Sijapati is a Lecturer of Population, Patan Multiple Campus, TU, Nepal
} 


\section{Introduction}

This article basically focused in gender theory, like wise; Gender and Development (GAD) and gender mainstreaming are evolutions of the women in development (WID) programs of the 1970s. WID approaches responded to the realization that early development efforts were gender blind and hence male oriented. Third world women were often portrayed as generally poor, illiterate, and ignorant. Their unequal economic and social status, low literacy levels, poor health, high maternal mortality and disadvantages under the law stemmed from their lack of participation in development (Parpart, Jane L., Shirin M. Rai, Kathleen Staudt, 2002). Boserup first clarified this position and advocated incorporating women into development projects, particularly into those that would provide them with economic independence and enhanced standing in their families and communities (Boserup, Ester. 1970). This was vigoously supported by many other academics and feminists, and major bilateral and multilateral donors added women's programs to their portfolios and promoted development policies that called for the inclusion of women. While women made gains in health (especially family planning), in literacy, and in income earning, much was left undone. It rapidly became clear that simply adding women to development was a flawed approach. Female academics and activists from the South and North joined with the female staff of major donor institutions to assess both the problems and the outcomes of WID approaches and to call for new directions in addressing women's issues. Among the problems identified with WID approaches were the following (Rai, Shirin M. 2002). Relegating third world women to a homogenous category of passive, backward victims denied their extensive diversity ${ }^{4}$ and robbed them of agency and voice ( Pearson, Ruth, Anne Whitehead, and Kate Young) 1984.The belief that simply extending education and employment opportunities to women would solve their problems was an unexamined, problematic assumption (Rai, 2001). Treating women as "add-ons" in development activities meant they were of secondary importance and hence often received token funding. Evidence indicated third world women were often marginalized and disadvantaged by development policies and practices. Largely missing in WID approaches was any clear understanding of women's subordination. The results of women's government units to promote their incorporation in national development schemes also appeared largely unsuccessful Pearson, (Ruth and Cecile Jackson. 1998). Gender and development programs emphasize the limitations of focusing on women only and stress the necessity of realizing that women's lives are grounded in social relations with men that set parameters for their actions, beliefs, and outlooks (Baden, Sally and Anne Marie Goetz 1998). Moreover, development policies and practices have definite masculine and feminine attributes that are inherent in public/private distinctions, (Baden and Goetz) in definitions and analyses of households, ${ }^{10}$ and in interventions such as credit, technological inputs, and the new 
managerial approach that drives many development projects. ${ }^{11}$ Solutions range from those calling for women's empowerment to challenge patriarchal and political-economic inequalities ${ }^{12}$ to calling for gender to be used as a "lens through which to understand the dynamics of social and economic change in societies in transition (Moser, Caroline O.N. 1993). GAD encourages the incorporation of broader conceptual and practical approaches to donor, NGO, and state development efforts. They moved from primarily woman-centered development projects and welfare definitions of women's needs to a broader focus on gender relations that generate and perpetuates gender inequalities. GAD also recognizes that men must commit and acquiesce to meeting the strategic as well as practical needs of women. ${ }^{14}$ Moreover, GAD approaches accept that gender relations are social, historical, cultural, and religious, and as such they can be altered (Mies, Maria. 1994). The GAD perspective is not without its critics, however. Academics such as Maria Mies write that the use of gender has had the effect of, virtually excluding women again from the public discourse (Mies, Maria. 1994).

\section{Objective}

- To find out the gender inclusion in local government to National Level

- To find out the gender and good governance in Nepal

\section{Methodology}

This article is based on cross sectional descriptive and analytical type of research design. Descriptive research aims to accurately and systematically describe a population, situation or phenomenon. It can answer what, where, when and how questions, but not why questions. It can use a wide variety of research methods to investigate one or more variables. It is an appropriate choice when the research aim is to identify characteristics, frequencies, trends, and categories. Descriptive research is usually defined as a type of quantitative research; though qualitative research can also be used for descriptive purposes. This design should be carefully developed to ensure that the results are valid and reliable. Among the three main types of research i.e. exploratory, descriptive and analytical, this study is mainly descriptive in nature. The situations are explored in terms of gender, equality and inclusion in local government. However, the research location areas like hill and terai are not similar as mentioned in some of the variables need to be compared in between the research areasA mixed-method information collection approach are used. Basically, information needed to answer the research queries collected from both primary and secondary sources. The information collected through literature review to develop qualitative and quantitative techniques. The research hypothesis tested based on primary data. However, secondary sources will supplement the empirical findings through various means and techniques. All available secondary data including progress and evaluation reports of related research and studies, seminar reports and journals, books, reports of 
policies and strategies and CBS/NPC, GESI and election commission reports, DDC profile, municipality and rural municipality profiles was reviewed and analyzed. This means that information was collected through multiple sources viz. libraries, government and nongovernment offices to ensure the reliability of the research.

\section{Result and Discussion}

\section{The Legal Framework for Local Government in Nepal}

In the early 1990's, the political structure of Nepal changed from a, “...panchayat (local government) system with an absolute monarch to a constitutional monarchy with a bicameral parliament, an ex- ecutive cabinet responsible to parliament, and an independent judiciary." 78 The constitution approved at that time guarantees fundamental rights and equal application of the law to all citizens without regard to ethnicity, caste, sex, or religion. The enormous diversity in ecological regions, cultures, and languages means that progress in human and social development is often uneven, and resources are not evenly allocated. This is particularly the case for women. They are still subject to strong patriar- chal customs and values including early marriage, limited rights to divorce and remarriage, and un- equal access to basic, education, health services, economic opportunities, and representation under the law including the right to inherit land, property, and wealth.

In the last decade, the Nepalese government introduced the Eighth (1991-1996), Ninth (1997- 2002), and Tenth (2003-2007) Development Plans all of which made the decentralization of govern- ment operations and procedures a top priority. Devolving power and authority to local government was seen as a way to fight poverty. In 1999, the Local Self-Governance Act was passed and, "...is the major achievement of the government." is this Act that has provided for women's representation in local government bodies by both nomination and election. The Local Self-Governance Act Report notes that numerous tasks are now the responsibility of local bodies: management and delivery of almost all sectoral services; preparation of both long-term and short-term policies, plans, and pro- grams; coordination of and partnership with NGOs and civil society in development; and promotion of the private sector in service delivery and revenue generation.

The country is divided into five regions that are subdivided into 75 districts. The Act establishes a two-tier system of local government with the district as the highest tier. The district development committee is the governing body. The basic tier of local government is composed of the local bodies in villages and municipalities. A village has three local bodies: ward committees, a village develop- ment committee (VDC) and a village council. There are nine wards in each village, and each ward has a committee that is composed of five members. One member is the chair, and one must be a woman. All members are elected by adult franchise. That means that in each village there would be a minimum of 9 women out of 45 ward committee members equal to 20 percent. The VDC is the executive body of local 
government and is composed of the chairs of the nine wards. Each VDC in turn elects a chair and vice-chair and nominates two additional members from the ranks of the ward. One of the nominated members must be a woman. That means that out of the total of 13 VDC members, only one must be a woman 8 percent. The village council is the legislative body of local government. It consists of all 45 ward committee members and 6 members nominated from the poor, ethnic, religious, and tribal minorities 1 of whom must be a woman. That means that out of a total of 53 members, 10 must be women (approximately $19 \%)$. The councils meet only a few times a year.

In 1997, more than 100,000 women participated in the VDC elections, and 36,000 were elected. However, in other branches of local government, women were only marginally represented. For example, only 289 women were elected ward chairs out of a total of 3,999 wards. Of the 26 women who ran for membership in the district development committees, only 8 were elected, and only 1 woman was elected vice-chair. No elections have been held since 1997 because of the deteriorating political situation. The project therefore invited women whose elected terms had expired, women who had been nominated for positions in councils, and female leaders from various community organizations to participate in capacity building.

The Local Self-Governance Act prepared policy recommendations for improving the situation of the elected and nominated women members. The review pointed out that the language and thinking of the act are primarily male oriented. Males have the majority of positions at all levels of government and the Act consistently uses masculine pronouns. One of the major structural problems of the Act is that elected female members are not specifically included in the executive bodies of local government though they are included in the legislative bodies. For example, a woman elected to a ward committee is automatically part of the village council (the legislative body), but the council meets once or twice a year only to approve the budget. The VDCs, on the other hand, are the executive bodies of local government and have control over development activities. The Act includes nominated female representatives in the VDCs, but they are not elected by a constituency which makes it difficult for them to be effective.

Various committees and subcommittees are formed to handle local government responsibilities, but there is no provision in the Act for women to be included on them. This includes membership on the critically important decentralization, implementation and monitoring committee, the accounts committee, the arbitration board, and the coordination committees. There is also no provision that women must be part of the quorums necessary to hold meetings at all levels of local government nor is it compulsory that women or ethnic minorities be present for meetings to be held. Gender and minority issues are treated under 
"miscellaneous," "social welfare," or under the separate category of "women and helpless people." Their issues are not mainstreamed into the policies of the local bodies, and there is no provision for gender or minority issues to be included in local projects. The VDC is expected to give priority to projects that provide direct benefit to women as well as backward classes and children. However, there is no mandate to include these segments of the population in project feasibility studies. The Act only indicates that priority is to be given to projects on the basis, "...of the number of the population to be benefited from the project and the type of benefit.” This means that in reality, few projects are designated for women, backward classes, or children. Chapter 8 lists recommendations for changes in the Act.

\section{Women candidates in national level}

As table shows, the number of women candidates for national elections of Nepal was very low in comparison to men candidates. The numbers of women candidates were increasing gradually; however, in term of percentage, women's candidacy has not been increased significantly. There were 80 women candidates in HoR election in 1991; in contrast, there were 1265 men candidates. The ratio between women and men candidates of the election was 1:16. It was a huge gap in gender wise candidacy.

Table: 1 Gender wise elections of Nepal candidates of general

\begin{tabular}{|c|c|c|c|c|c|c|c|c|c|c|}
\hline Gender & \multicolumn{2}{|c|}{ Election 1991 } & \multicolumn{2}{|c|}{ Election 1994 } & \multicolumn{2}{|c|}{ Election 1999 } & \multicolumn{2}{c|}{ Election 2008 } & \multicolumn{2}{|c|}{ Election 2013 } \\
\hline & $\mathrm{N}$ & $\%$ & $\mathrm{~N}$ & $\%$ & $\mathrm{~N}$ & $\%$ & $\mathrm{~N}$ & $\%$ & $\mathrm{~N}$ & $\%$ \\
\hline Male & 1265 & 94.05 & 1356 & 94.04 & 2095 & 93.61 & 3577 & 90.65 & 5458 & 89.09 \\
\hline Female & 80 & 5.95 & 86 & 5.96 & 143 & 6.39 & 369 & 9.35 & 667 & 10.89 \\
\hline Third Sex & 0 & 0.00 & 0 & 0.00 & 0 & 0.00 & 0 & 0.00 & 1 & 0.02 \\
\hline Total & 1345 & 100.00 & 1442 & 100.00 & 2238 & 100.00 & 3946 & 100.00 & 6126 & 100.00 \\
\hline
\end{tabular}

Gender Wise Elected Candidates of national elections of Nepal in FPTP electoral system

\begin{tabular}{|c|c|c|c|c|c|c|c|c|c|c|}
\hline Male & 198 & 96.59 & 198 & 96.59 & 193 & 94.15 & 210 & 87.50 & 230 & 95.83 \\
\hline Female & 7 & 3.41 & 7 & 3.41 & 12 & 5.85 & 30 & 12.50 & 10 & 4.17 \\
\hline Total & 205 & 100.00 & 205 & 100.00 & 205 & 100.00 & 240 & 100.00 & 240 & 100.00 \\
\hline
\end{tabular}

Source: Election Commission 1992, 2051 B.S., 2056 B.S., 2065 B.S. \& 2070 B.S.

In Constituent Assembly election 2013, 667 women filed their candidacy. It shows the increasing level of women's involvement in electoral politics. But, the percentage of women 
could not exceed 11 of total candidates. In the election, the ratio between women and men candidates reduced in point of 1:10; however, still, a visible gap exists. Very few women candidates could win in the national elections. Only 7 women elected in both HoR elections 1991 and 1994 out of 205 seats. The success percent of women candidates was 8.75 percent in 1991 and 8.14 percent in 1994. Similarly, 12 women candidates won the HoR election in 1999; the success of women candidates was 8.39 percent in the election. Likewise, 30 women candidate won the CA election in 2008 out of 240 seats. The success of women candidates was 8.13 percent. Only 10 women candidates won the CA election 2013 and the percent of the success of women candidates was 1.50.

Table: 2 Name of Parties and Total Elected CA Members by Sex for Parliament Members in 2074 Election

\begin{tabular}{|l|l|l|l|l|l|l|l|}
\hline \multirow{2}{*}{$\begin{array}{l}\text { S. } \\
\text { N }\end{array}$} & \multirow{2}{*}{ Name of party } & \multicolumn{2}{l}{ Male } & \multicolumn{2}{l}{ female } & \multicolumn{2}{l|}{ Total } \\
\cline { 3 - 8 } & & $\mathbf{N}$ & $\mathbf{\%}$ & $\mathbf{N}$ & $\mathbf{\%}$ & $\mathbf{N}$ & $\mathbf{\%}$ \\
\hline 1 & CPN UML & 78 & 49.06 & 2 & 33.33 & 80 & 48.48 \\
\hline 2 & Nepali Congress & 23 & 14.47 & & - & 23 & 13.94 \\
\hline 3 & Ne KA PA. Mao Badi (Kendra) & 33 & 20.75 & 2 & 33.33 & 35 & 21.21 \\
\hline 4 & Rastriya Janta Party Nepal & 11 & 6.92 & - & - & 11 & 6.67 \\
\hline 5 & Sangiya Samajbadi Forum & 10 & 6.29 & - & - & 10 & 6.10 \\
\hline 6 & NayaSakti Party Nepal & 1 & 0.63 & - & - & 1 & 0.61 \\
\hline 7 & Nepal Majdur Kisan Party & 1 & 0.63 & - & - & 1 & 0.61 \\
\hline 8 & Rastriya Janmorcha & - & - & 1 & 16.67 & 1 & 0.61 \\
\hline 9 & Ra. Pra. Pa. & 1 & 0.63 & - & - & 1 & 0.61 \\
\hline 10 & Sotantra & 1 & 0.63 & 1 & 16.67 & 2 & 1.21 \\
\hline Total & $\mathbf{1 5 9}$ & $\mathbf{1 0 0 . 0}$ & $\mathbf{6}$ & $\mathbf{1 0 0}$ & $\mathbf{1 6 5}$ & $\mathbf{1 0 0 . 0}$ \\
\hline
\end{tabular}

Source: Election Commission of Nepal, 2074.

Among 165 elected CA members, 48.48 percent belongs from CPN UML, 13.94 percent belongs from Nepali Congress, 21.21 percent belongs from Nekapa Maoist (Kendra), 6.67 percent belongs from RastriyaJanata Party Nepal, 6.10 percent belongs from Sangiya Samajbadi Forum, 0.61 percent belongs from NayaSakti Party Nepal, 0.61 percent belongs from Nepal MajdurKisan Party, another 0.61 percent belongs from Raprapa and 1.21 percent belongs from Sotantra. Moreover, CPN UML has taken $1^{\text {st }}$ position, Nekapa Maoist Party (Kendra has taken $2^{\text {nd }}$ position, Nepali Congress has taken $3^{\text {rd }}$ position, Rastriya janata 
Party has taken $4^{\text {th }}$ position, SanghiyaJanabadi Forum Party has taken $5^{\text {th }}$ position, Sotantra has taken $6^{\text {th }}$ position and other rest of them are in $7^{\text {th }}$ position.

Table: 3. Broad Age Group of Parliament Elected Members by Sex, in 2074 Election

\begin{tabular}{|l|l|l|l|l|l|l|l|}
\hline \multirow{2}{*}{ S.N } & \multirow{2}{*}{ Age Group } & \multicolumn{2}{l}{ Male } & \multicolumn{2}{l|}{ female } & \multicolumn{2}{l|}{ Total } \\
\cline { 3 - 8 } & & $\mathbf{N}$ & $\mathbf{\%}$ & $\mathbf{N}$ & $\mathbf{\%}$ & $\mathbf{N}$ & $\mathbf{\%}$ \\
\hline 1 & $30-35$ & 4 & 2.52 & 1 & 16.67 & 5 & 3.03 \\
\hline 2 & $36-40$ & 7 & 4.4 & - & - & 7 & 4.24 \\
\hline 3 & $41-45$ & 18 & 11.32 & 1 & 16.67 & 19 & 11.52 \\
\hline 4 & $46-50$ & 38 & 23.9 & 2 & 33.33 & 40 & 24.24 \\
\hline 5 & $51-55$ & 31 & 19.5 & 2 & 33.33 & 33 & 20.0 \\
\hline 6 & $56-60$ & 33 & 20.75 & - & - & 33 & 20.0 \\
\hline 7 & $61-65$ & 19 & 11.95 & - & - & 19 & 11.52 \\
\hline 8 & $66-70$ & 8 & 5.03 & - & - & 8 & 4.85 \\
\hline 9 & 71 and above & 1 & 0.63 & - & - & 1 & 0.61 \\
\hline Total & & $\mathbf{1 5 9}$ & $\mathbf{1 0 0 . 0}$ & $\mathbf{6}$ & $\mathbf{1 0 0}$ & $\mathbf{1 6 5}$ & $\mathbf{1 0 0 . 0}$ \\
\hline
\end{tabular}

Source: Election Commission of Nepal, 2074.

While analyzed by board age group of an Elected Parliament Members, highest (24.24\%) percent are of aged group 46-50 years in total and as well as in both male (23.9\%) and female (33.33\%). Second highest percent male are in age group 56-60 years and female are in 51-55 years' age group. Third highest are in aged group 41-45 years old, 11.52 percent in total, 11.32 percent in male and 16.67 percent in female. However, majority members are aged above 40 years and below 60 years. Above 70 years' members are only 0.61 percent. And below 40 years old also are minority.

Table: 4. Local Elected Members by Province level in 2074 Local Election (in Number)

\begin{tabular}{|l|l|l|l|l|l|l|l|}
\hline \multirow{2}{*}{ S.N } & \multirow{2}{*}{ Numbers } & \multicolumn{4}{|l|}{ No of Candidates members } & \multicolumn{3}{l|}{ Total Elected Members } \\
\cline { 3 - 8 } & & Male & Female & Total & Male & Female & Total \\
\hline 1 & Province-1 & 15254 & 9813 & 25067 & 3554 & 2489 & 6043 \\
\hline 2 & Province -2 & 22861 & 14387 & 27248 & 3895 & 2723 & 6618 \\
\hline 3 & Province -3 & 14726 & 8887 & 23613 & 3433 & 2359 & 5792 \\
\hline 4 & Province-4 & 7598 & 5057 & 12655 & 2317 & 1617 & 3934 \\
\hline
\end{tabular}




\begin{tabular}{|l|l|l|l|l|l|l|l|}
\hline 5 & Province -5 & 14024 & 9010 & 23036 & 3017 & 2116 & 5133 \\
\hline 6 & Province -6 & 7554 & 4848 & 12402 & 2211 & 1476 & 3687 \\
\hline 7 & Province -7 & 8502 & 5841 & 14343 & 2262 & 1572 & 3834 \\
\hline \multicolumn{2}{|l}{ Total } & 90519 & 57843 & 148364 & 20689 & 14352 & 35041 \\
\hline
\end{tabular}

Source: Election commission of Nepal, 2074.

Note: Only two new candidates are in province five who have third gender.

Table 4. Local Elected Members by Province in 2074 local

\begin{tabular}{|l|l|l|l|l|l|l|l|l|}
\hline \multirow{2}{*}{ S.N } & \multirow{2}{*}{ Province } & \multicolumn{3}{l}{ No of Candidates members } & \multicolumn{3}{l}{ Total Elected Members } \\
\cline { 3 - 9 } & & Male $\%$ & Female $\%$ & Total \% & Mal\% & Female \% & Total \\
\hline 1 & Province-1 & 16.85 & 16.96 & 16.89 & 7.26 & 17.34 & 17.25 \\
\hline 2 & Province -2 & 25.26 & 24.87 & 18.37 & 18.92 & 18.97 & 18.89 \\
\hline 3 & Province -3 & 16.27 & 15.36 & 15.92 & 16.67 & 16.44 & 16.53 \\
\hline 4 & Province-4 & 8.39 & 8.74 & 8.53 & 11.25 & 11.27 & 11.23 \\
\hline 5 & Province -5 & 15.49 & 15.58 & 15.53 & 14.65 & 14.74 & 14.65 \\
\hline 6 & Province -6 & 8.35 & 8.38 & 8.36 & 10.74 & 10.28 & 10.52 \\
\hline 7 & Province -7 & 9.39 & 10.10 & 9.67 & 10.99 & 10.95 & 10.94 \\
\hline Total & & 100.0 & 100.0 & 100.0 & 100.0 & 100.0 & 100.0 \\
\hline Local Elected Members by Province in 2074 Local Election. & & \\
\hline 1 & Province-1 & $60.85 \%$ & 39.15 & 25067 & 58.81 & 41.19 & 6043 & \\
\hline 2 & Province -2 & 83.9 & 16.1 & 27248 & 41.15 & 27.23 & 6618 & \\
\hline 3 & Province -3 & 62.36 & 37.64 & 23613 & 59.27 & 40.73 & 5792 & \\
\hline 4 & Province-4 & 60.04 & 39.96 & 12655 & 58.9 & 41.10 & 3934 & \\
\hline 5 & Province -5 & 60.88 & 39.11 & 23036 & 58.78 & 41.22 & 5133 & \\
\hline 6 & Province -6 & 60.91 & 39.09 & 12402 & 59.97 & 40.03 & 3687 & \\
\hline 7 & Province -7 & 59.28 & 40.72 & 14343 & 59.0 & 41.0 & 3834 & \\
\hline Total & & 61.01 & 38.98 & 148364 & 59.04 & 40.96 & 35041 & \\
\hline
\end{tabular}

Source: Election commission of Nepal, 2074.

While analysed of number of candidates and numbers of elected members for local government by province, total 148364 members were candidates for election in all 7 
provinces but only 35041 (23.62\%) members are elected. As gender, among 90519 male candidates, 20689 (22.86\%) are elected. Someway, among 57843 female candidate 14352 (24.81\%) are elected. As province wise analysed, in province No 1, total numbers of candidates were 25067. Out of them 6043 (24.11\%) are elected and 58.81 percent are male and 41.19 percent are female. In province No. 2, total numbers of candidates were 27248 . Out of them 24.29 percent are elected and 58.85 percent are male and 41.15 percent are female. In province No. 3, total numbers of candidates were 23613. Out of them 5792 (24.53\%) are elected and 59.27 percent are male and 40.73 percent are female. In province No 4 total number of candidates was 12655. Out of them 3934 (31.1\%) are elected and 58.9 percent are male and 41.10 percent are female. In province No. 5 total numbers of candidates were 23036. Out of them 5133 (22.28\%) are elected and 58.78 percent are male and 41.22 percent are female. In province No. 6 total numbers of candidates were 12403 . Out of them 3687 (29.73\%) are elected and 59.97 percent are male and 40.03 percent are female. In the province No. 7 total numbers candidates were 14343. Out of them 3834 (26.73\%) are elected and 59 percent are male and 41 percent are female. Among the elected candidates, gender inclusion in local government is quite high than allocated by Nepal Constitution 2072 as well as election manifesto 2074 of different political parties because, the Nepal Constitution 2072 mentioned that each and every political parties should at least 33 percent women included in their political activities including election too.

\section{Conclusion}

Nepali women have constantly challenged the patriarchy in all its dimensions. They initiated a movement for their rights - one that has been largely ignored in the literature. Though the Constitution of 1990 brought much hope for the country's political transformation and guaranteed considerable political rights, civil liberties, and individual freedom, it was only able to introduce a few changes regarding gender-discriminatory laws. After the signing of the CPA and the promulgation of the Interim Constitution, the one-third representation in government structures for women was secured. Consequently, the motivation for women to engage in the election process also increased. The Constituent Assembly election of 2008 became historic as women's participation outnumbered men-an example of such motivation. The Constitution of 2015 promised at least 33\% of women's participation in all the State operations. At the local level, 41 per cent of newly elected officials were women along with 34 per cent of Provincial assembly seats reserved for women. However, despite the promise of including women's representation in the State restructuring, women have been denied political power at the local level. Women candidates have been elected in the Parliament simply to fulfill the quota of including women representatives. As noted above, many operational problems in the daily execution of Parliamentary duties persist due to entrenched discrimination. The women of Nepal are still not freed from the burden of living in a patriarchal society. Too often their capacity to participate in Parliament at quota levels has been questioned, rather than holding up for scrutiny the forms of discrimination and lack of opportunities that have underprepared women for equal participation. The influence of women in decision-making and constitution-building process remains limited. Though women have become successful in acquiring higher positions (e.g., President of Nepal, 
earlier Chief Justice of Supreme Court and Speaker of the Parliament), achievements not even possible to imagine two decades ago, the achievements attained thus far are not enough. Continued, concerted action among all actors is essential.

Nepal is known for its diversity. The country is home to 125 officially recognised caste and thnic communities and boasts 122 different languages with a range of socio-cultural practices. The total population, approaching about 29 million, lives in different geographical regions, including the Southern Plains (Tarai-Madhes), Mid-Hills and Mountains. The economic status, education, health, level of exposure to development, and access to resources varies from urban to rural, east to west and north to south. Deep-rooted structural inequalities are linked to ethnic identity, language, religion, region, gender, and economic status resulting in a range of discriminatory practices. Grievances arising from political marginalization, caste discrimination, and exclusionary practices of the state perpetuate a historical divide between communities. The implementation of legal reforms and policies enacted to improve gender equality and social inclusion at the national and local level have been weak (Asian Foundation, 2017).

As discussion with local justice committees and local people of Jhapa district, family/ home and children are being worse due to the women whose (husband) man went to foreign labour work and there is difficult for punishment to those women due to their political affiliation. So, it is being difficult to provide the justice to man (husband) those are suffering from such types of problems from their wife. There are no specific living rooms for elected ward committee women members and inclusive representative in half of the wards of Lalitpur metropolitan city and Godawari municipality of Lalitpur district. The all responsibilities of them are performing by ward chairman. Very limited budget is allocated in women's sectors by all local governments of study areas. The allocated budget is unnecessarily utilizing name of just for finishing the budget. The conducted trainings are traditional types which are ineffectiveness, nonproductive, non job oriented, non capacity building, those are just budget spending purpose. Their own family members and relatives are benefited by such types of budget. Local election act, 2074 had provided the gurentee one major post (Mayor or Deputy Mayor and Chairman or vice Chairman) for female, the election and slection both are different political parties. So, they were nomination both male and female. Then, the both vital post are elected males. At condition, females' problem and issues are not properly address and discussion. Increasing local government authority over service provision is pursued in part to reduce the gap between citizens and government authorities, as local government is considered closer to constituents. Whether or not LGs are able to continue to provide and improve services and develop infrastructure will be critical to the success of the new governance structure. In particular, research may choose to assess some of the indicators based on local government service provision in selected sectors, such as health, education, water and sanitation, and roads. Female participation has massively increased in local government after formulation the gender inclusive policies in Nepal. Patriarchy continues to dominate the discourse not only around gender issues in local level, but also around broader women's issues. Women at local level government are to just fill 
numbers and fulfill the quota requirement of political parties or they have understood knowledge about the compulsory women participation by laws and policy.

\section{References}

(ADB. 2004). Report of the Review of Local Self-Governance Act in Nepal: RETA 6008. Nepal.

Parpart, Jane L., Shirin M. Rai, Kathleen Staudt (2002). Rethinking Empowerment.Gender and Development in a Global/local World. London and New York: Routledge.

Boserup, Ester (1970). Women's Roles in Economic Development. London: George Allen and Unwin.

Rai, Shirin M. (2002). Gender and the Political Economy of Development: From Nationalism to Globalization. Cambridge, U.K.: Polity Press.

Pearson, Ruth, Anne Whitehead, and Kate Young (1984). "Introduction: The Continuing Subordination of Women in the

K. Young, C. Wolkowitz and R. McCullagh (eds) (1981). Gender planning in the third world: Meeting practical and strategic gender needs:Development Process Marriage and the Market: Women's Subor-dination Internationally and Its Lessons. London.

Pearson, Ruth and Cecile Jackson (998). "Introduction: Interrogating Development” in Cecile Jackson and Ruth Pearson (eds) (1998). Feminist Visions of Development: Gender, Analysis, and Policy. London: Routledge.

Baden, Sally and Anne Marie Goetz (1998). "Who Needs (Sex) When You Can Have (Gender)? Conflicting Discourses on Gender at Beijing," in Cecile Jackson and Ruth Pearson (eds). Feminist Visions of Development: Gender, Analysis and Policy. London: Routledge.

Scott, Catherine V. (1995). Gender and Development: Rethinking Modernization and Dependency Theory, 1995. Boulder and London: Lynne Rienner Publishers.

Kandiyoti, Denizm (1998). “Gender, Power and Contestation” in Cecile Jackson and Ruth Pearson (eds). Op. cit.

Moser, Caroline O.N. (1993). Gender Planning and Development Theory: Practice and Training. London: Routledge.

Mies, Maria (1994). “Gender' and Global Capitalism.” In Leslie Sklair ed. Capitalism and Development. London and New York: Routledge. 